The International Journal of

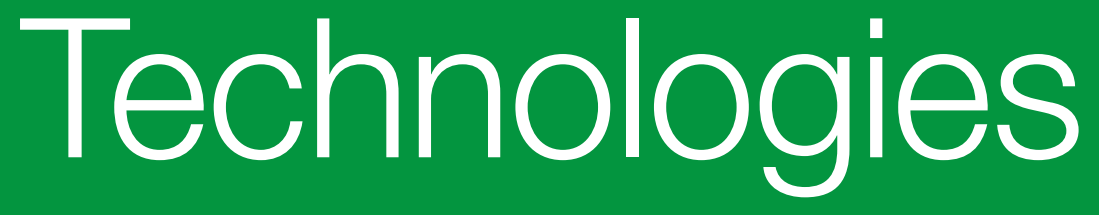

in Learning

Perspectives on Schooling from Early

Adolescent Video Diaries

GEORGINA BARTON AND NAN BAHR

(1) COM MON

W G R O U U D 
THE INTERNATIONAL JOURNAL OF TECHNOLOGIES IN LEARNING

http://thelearner.com/

First published in 2013 in Champaign, Illinois, USA

by Common Ground Publishing

University of Illinois Research Park

2001 South First St, Suite 202

Champaign, IL 61820 USA

www.CommonGroundPublishing.com

ISSN: 2327-0144

(C) 2013 (individual papers), the author(s)

(C) 2013 (selection and editorial matter) Common Ground

All rights reserved. Apart from fair dealing for the purposes of study, research, criticism or review as permitted under the applicable copyright legislation, no part of this work may be reproduced by any process without written permission from the publisher. For permissions and other inquiries, please contact <cg-support@commongroundpublishing.com>.

The International Journal of Technologies in Learning is a peer-reviewed scholarly journal. 


\title{
Perspectives on Schooling from Early Adolescent Video Diaries
}

\author{
Georgina Barton, Griffith University, Australia \\ Nan Bahr, Queensland University of Technology, Australia
}

\begin{abstract}
The aim of this project was to gain the voice of the early adolescent (aged between 11 and 13 years) about the things that are genuinely important to them in their lives. Eight participants were asked to record a private video diary entry each night for one week. A number of thematic topics were identified including: their experiences and perspectives on school curriculum and assessment, opinions about schooling structures, and importance of friendship and family. Giving young adolescents the opportunity to voice their opinions has been valuable in gaining insight to the relative impacts of teaching and learning approaches in their school contexts and the issues they consider as the most important in their lives.
\end{abstract}

Keywords: Adolescents, Schooling, Video Diary

\section{Section Heading}

$\mathrm{R}$ esearch into adolescents and education has increased over the past decade (Bahr \& Pendergast, 2007; Chadbourne, 2003; Jackson \& Davis, 2000; Luke, et al 2002). This is largely due to the fact that it had previously been unrecognised as a distinct area of study within the education field. Discipline areas such as psychology and developmental studies tended to be responsible for such investigation (Swanson et al. 2010; Zachry, 1940). In recent times, however, the Middle Years of Schooling (MYS) have been recognised for the unique aspects associated with adolescence. This research focusses both on developmental factors but also the distinct changes that occur within the school context, including pedagogy, for example in the content areas. In Australia there is great change occurring in education with the introduction of a national curriculum and with it new pedagogical approaches. These changes will impact greatly on the middle years and as such, various state jurisdictions have released recent statements and/or agendas focusing on their educational plans.

The Middle Years Schooling Association (MYSA) in Australia for example, published a position paper in 2008. It acknowledges that the middle years of schooling "is an intentional approach to teaching and learning" that aims to engage young people aiming for overall positive academic outcomes. The position paper focuses on a model of middle schooling that presents the relationship between three impacting factors on middle years' students: people, practices and places. 


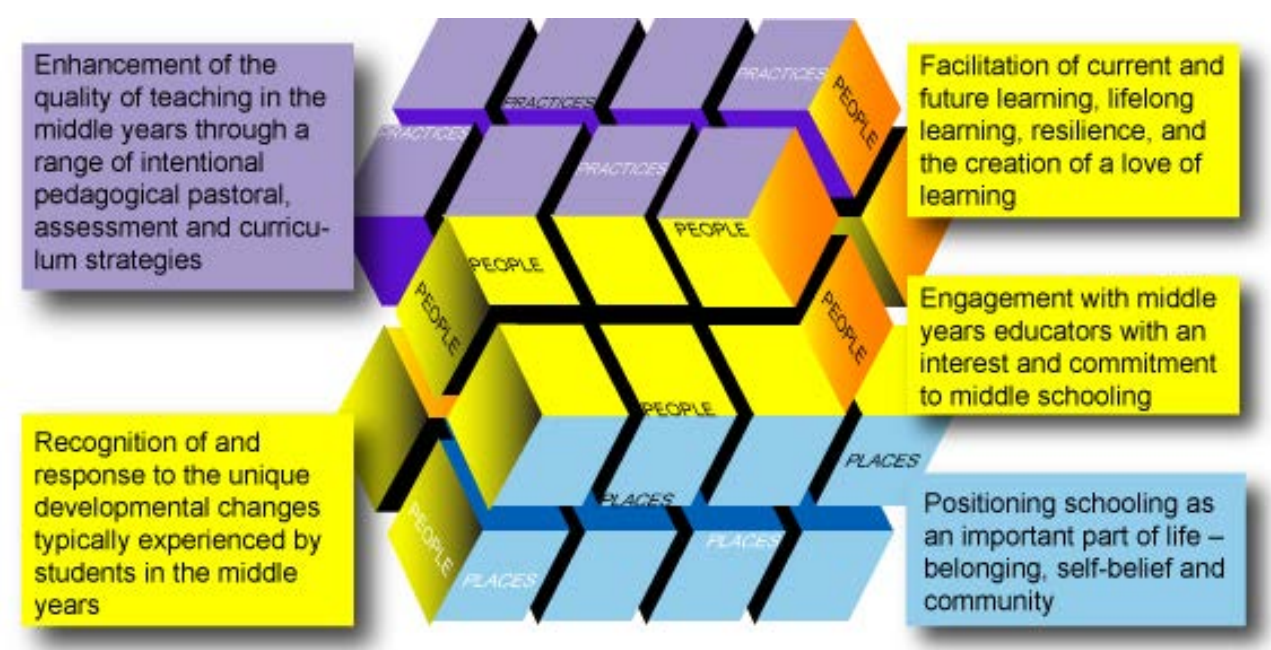

Figure 1: MYSA Middle Schooling Model: People, Practices and Places (MYSA, 2008)

The model provides a useful framework to investigate what is happening in young people's lives and how these may impact on their schooling experience. This in turn has influenced a number of states to consider their approaches to middle years of schooling.

Similarly, in 2008 the Australian government published a declaration on educational goals for young Australians. It states that:

The middle years are an important period of learning, in which knowledge of fundamental disciplines is developed, yet this is also a time when students are at the greatest risk of disengagement from learning. Student motivation and engagement in these years is critical, and can be influenced by tailoring approaches to teaching, with learning activities and learning environments that specifically consider the needs of middle year's students (p. 12).

In Queensland, 2014 sees a major change in the structure of schooling for all Year 7 students (aged 11-12 years of age) moving to high school with the view of schooling best meeting middle years' students needs.

Despite the fact that the middle years of school are noted for their distinctiveness some are concerned that there has been a rapid decline in meaningful policy and consideration of middle years (Bahr \& Crosswell, 2011). Additionally, recent statistics still show high attrition rates and poor results in national testing particularly for those from low socio-economic backgrounds (Shanahan \& Shanahan, 2008). Further, while there has been a dramatic increase of investigation into the middle years of schooling little has focussed on early adolescence (often referred to as Tweens, Wormali, 2006 - in between early years and teenage years) and what does exist is research lying mostly in the 'outsider' observer approach. Often researchers report on what they feel is important for Tweens based on data from teachers, parents and other key significant others in their lives. These studies also involve students largely via interview or survey data where they are asked what they think about particular aspects of schooling but these tend to be narrow investigations of specific topics such as individual learning needs for children with disabilities (Mealings \& Douglas, 2010); or external education programs like drug and alcohol education (Dean, 2010; Deas, 2009) and so forth. 
Gidley and Hampson (2008) discuss the need for integrated perspectives from a number of stakeholders on future schooling so that students' needs are best met. Despite the sentiment that schooling for young people is not reaching its potential, past research has based its opinion on evidence only in the form of one-to-one interview or survey material.

\section{Background}

This paper notes the need of the 'direct' voice of the student - on their experiences, perhaps giving insight to their perspectives on learning both within and across disciplines, and the connections between their broader lives and their daily schooling lives. The fundamental premise was that adolescents will provide their views on the things of importance to them if the research format allows them to do so freely. This is an atypical stance for adolescent research.

Most research into adolescent perspectives pre-sets the focus and direction of interactions with young people by setting the enquiry and observations on narrow parameters based on an existing theoretical frame. Typically, adolescent research methodology utilises observation, targeted surveys, student achievement matrices, and/or semi structured interviews based on the researcher's perceptions of what will be important for adolescents and sets out to confirm or deny this. We propose that a more interpretivist phenomenological approach might provide better insight to the actual interests and concerns of young people. The types of topics that have engaged researchers of young adolescence have been classroom learning experiences (e.g., Luke et al, 2002), identification of dis/engaging aspects of school contexts (e.g., Chadbourne, 2003), learning within and across disciplines (e.g. Jackson and Davis, 2000), and explicit connections between broader lives and daily schooling (e.g., Rideout et al, 2005). It is not clear however, if these are the actual key interests of the young people themselves.

As an adult research community we have come to believe that young adolescents are disengaging from school (Luke et al, 2002), that most school experiences are not naturally aligned to their interests (MYSA, 2008), and that their focus is primarily on their peers. The present research aims to determine if these are indeed the preoccupations and understandings of young adolescents.

The research questions that have underpinned our research are:

- What aspects of their daily life do young adolescents reflect upon most?

- What views do young adolescents commonly express about their schooling?

- Who appear to be the important influences in the daily lives of young adolescents?

\section{Method}

Adolescent participants were asked to record a video diary (see Noyes, 2004) each night for one week with the use of Flip $\subset$ Video recorders. Participants also provided some general demographic information; gender, age, type of school, year level, and parental circumstances. Ethical clearance from the University Human Research Ethics Committee was obtained, and informed consent from parents and each individual participant was required.

The participants were given a list of prompt questions (Table 1) to assist them in recording their nightly video entries. 
Table 1: Questions and prompts for student video diary entry

\begin{tabular}{|c|c|}
\hline \multicolumn{2}{|c|}{ BEGINNING OF THE WEEK (Sunday Night) } \\
\hline 1 & How do you feel about school this week? \\
\hline 2 & What are you expecting to be doing? \\
\hline 3 & If you could have your way, what would your school week be like? \\
\hline 4 & What are you looking forward to? \\
\hline 5 & What are you not looking forward to? \\
\hline \multicolumn{2}{|c|}{ EACH NIGHT (Monday - Thursday Night) } \\
\hline 1 & What thoughts do you have of your school learning today? \\
\hline 2 & Where did you feel at your best with your learning today? \\
\hline 3 & Was today a special day for you in any way? \\
\hline 4 & If there was something you could change about today, what would it be? \\
\hline 5 & $\begin{array}{l}\text { How do you feel about tomorrow? } \\
\qquad \begin{aligned} \bullet & \text { Friends } \\
\bullet & \text { Class time } \\
\bullet & \text { Special activities }\end{aligned}\end{array}$ \\
\hline \multicolumn{2}{|c|}{ END OF THE WEEK (Friday Night) } \\
\hline 1 & $\begin{array}{l}\text { Thinking back over the week, which school lessons were the best for you? } \\
\text { Why? }\end{array}$ \\
\hline 2 & If you could have your way, what would your school day be like? \\
\hline 3 & Do you like school? Why? \\
\hline 4 & What was the most exciting/enjoyable part of your week? \\
\hline 5 & $\begin{array}{l}\text { How do you feel about school next week? } \\
\qquad \begin{aligned} \bullet & \text { Friends } \\
\bullet & \text { Class time } \\
\bullet & \text { Special activities }\end{aligned}\end{array}$ \\
\hline
\end{tabular}

Each video recording was then mapped onto a coding sheet according to the topic discussed; type of emotion or feeling expressed by the student at the time (Lovas \& Holloway, 2001); and then commonalities evident across the student responses were identified. The authors note that there might be a number of variables presented in the data such as whether or not the students were 
feeling enthusiastic or tired in regard to completing their recording each night; whether or not the age difference or personalities of each child impacted on the amount recorded. We found that some recordings were much longer than others. However, it is important to note that each student approached their recordings in individual ways. This paper will discuss the results according to these themes identified through the interactive use of video data.

\section{Participants}

The participants were eight 11-13 year old adolescents. The eight adolescents selected came from a broad range of backgrounds and school contexts. The following Table 2 provides demographic information about each student.

Table 2: Demographic information about participants.

\begin{tabular}{|l|l|l|l|l|}
\hline $\begin{array}{l}\text { Student } \\
\text { No. }\end{array}$ & Age and Grade & Gender & $\begin{array}{l}\text { Type of school } \\
\text { attending }\end{array}$ & $\begin{array}{l}\text { No. of diary } \\
\text { entries }\end{array}$ \\
\hline 1 & 11 years, Grade 6 & Male & $\begin{array}{l}\text { All boys, Junior - } \\
\text { Years 4-7 }\end{array}$ & 6 \\
\hline 2 & 11 years, Grade 6 & Male & $\begin{array}{l}\text { Large P-12 - co- } \\
\text { education }\end{array}$ & 4 \\
\hline 3 & 12 years, Grade 7 & Male & $\begin{array}{l}\text { P-7 large public } \\
\text { primary school, co- } \\
\text { education }\end{array}$ & 6 \\
\hline 4 & 12 years, Grade 7 & Female & $\begin{array}{l}\text { P-7 multi-age, 1 } \\
\text { teacher public primary } \\
\text { school, co-education }\end{array}$ & 5 \\
\hline 5 & 13 years, Grade 7 & Female & $\begin{array}{l}\text { P-7 small catholic } \\
\text { primary school, co- } \\
\text { education }\end{array}$ & 5 \\
\hline 6 & 12 years, Grade 7 & Female & $\begin{array}{l}\text { P-7 medium sized } \\
\text { private primary school, } \\
\text { co-education }\end{array}$ & 6 \\
\hline 7 & 12 years, Year 7 & Male & $\begin{array}{l}\text { All boys, middle } \\
\text { school - years 7-9 }\end{array}$ & 5 \\
\hline 8 & 13 years, Year 7 & Male & $\begin{array}{l}\text { All boys, middle } \\
\text { school - years 7-9 }\end{array}$ & 6 \\
\hline
\end{tabular}

\section{Instruments: Video Diaries}

We adopted Buchwald, Schantz-Laursen and Delmar's definition of video diary entry as a "digitized diary used for research with purposes similar to those of studies using written diaries" (p. 13) however, we acknowledge that the "video responses [are] far more compelling" (Noyes, 2004, p. 198) as it allows the respondents themselves to comment on aspects most relevant to them without interruption from others. Noyes (2004) also notes that when he initially collected data via interviews he was "very much setting the agenda, and therefore felt unable to access some of the data that might be most pertinent to an analysis of the habitus. Whilst transcribing these interviews it became clear that [his] presence was limiting their contributions” (p. 196). We wanted to gain the early adolescent voice, direct from the horse's mouth so to speak, as it almost reverses conventional data collection on this age group. The use of video recorders provided first-hand 
evidence of the identified aims. This approach was also generative and simulated privacy for the participant providing individual ethnographies of their lives.

In addition we understood and recognised that young people are technologically literate and enjoy using new equipment (Rideout, Roberts \& Foer, 2005). It also enabled them to record their own video diary entry on their own in privacy allowing them to self-direct their responses and fulfil their need to be independent (Sessa, 1991) and at the same time guided with our prompt questions. Participants were given suggested questions and prompts that they could use to assist them in completing their video entries, however they were able to talk about any aspects they felt relevant in regard to their perspective on schooling. Participants were also permitted to share their diaries with their parents, and some chose to do so. We also found that the young participants enjoyed the use of video rather than feeling intimidated, as they were familiar with approaches such as this through the popular culture of 'Big Brother'. They all commented that the video cameras were fun to use.

Each video entry (a total of 43) was thematically coded according to what topic the participant discussed relating to their schooling and/or personal lives; and their overall emotional state (e.g., Lovas \& Holloway, 2001).

This paper will discuss the results according to the themes identified in the video data by drawing on comments made by the students.

\section{Results and Discussion}

The participants freely engaged in creating their video diaries with each preparing 5-6 individual entries over the week. All of the students in our study were enthusiastic participants in school and life generally, albeit in different ways. We found three common thematic areas of discussion as a result of coding each video diary entry. These were: 1 . Curriculum and assessment, 2. Schooling structure, and 3. Importance of friendship and family.

\section{Curriculum and Assessment}

Many comments were made in the video data about the curriculum the participants studied at school and the assessment set for them by teachers. It was clear that all of the participants had more than one teacher, in that there were a number of teachers that taught subjects other than their core subjects of English, Maths, Science, History and Geography and in some cases Religion. Subjects such as Art, Music, Drama, Languages and Sport were the responsibility of other more specialist teachers. The participants all commented on the fact that they liked having more than one teacher and they particularly looked forward to lessons that focussed on their non-core discipline areas:

On Mondays we have four different classes and only two core classes with our real teacher. It is pretty fun because we get to do different activities with different teachers because you get to experience different ways and feelings...I feel excited about tomorrow because we are doing Art and at the moment we are doing lino printing. (Student 7, Entry 2)

I look forward to music and Japanese and art. I enjoy those subjects as they are my favourites. I am also part of an astronomy club - my astronomy teacher has decided to call it "The Darkside". I have been attending it for most of last semester. Ever since term 1 week 6 I have been coming to the darkside. I am also in an afternoon chess club. (Student 2, Entry 4)

Conversely, some of the participants highlighted the subject areas they did not enjoy, which was largely due to the fact that they did not like the teacher, specific aspects about the learning activities, or misbehaviour from other students. 
I am not looking forward to tests and I don't like playing recorder - I love music but not recorder - I like playing guitar. (Student 3, Entry 1)

Classtime - nup - we have double maths, science, art and English. Gosh last week I went terrible in Art I couldn't get my picture to lino print. Science - boring, Maths - boring, English - boring. Every subject, except drama and computers - awesome! (Student 8, Entry 3)

Unfortunately there are some students whose behaviour is really immature they are rude they won't line up and they're picking fights with other students. I have a friend like me who tries to control the situation or reports it to the teacher and both of us agree that it is really immature and rude behaviour. (Student 2, Entry 2)

If I could change something about today it would probably be making people focus a bit more as there was a lot of chit chatting and we could have focussed a bit more and focus on assignments we have. (Student 5, Entry 1)

These types of comments are a direct challenge to the general expectation that most young adolescents are in a process of disengaging from school and that school contexts themselves by requiring them to work in concentrated ways are contributing to their disengagement. The participants of this study were interested in their schooling and did not appreciate the antics of students who were not on task and engaged.

Generally the students liked achieving positive results in their school work. They feel proud when they have done well. The students also aimed to please their teachers, parents and peers.

I felt best at my learning today in Maths when we were learning the area of trapezoids. It was really quite challenging but when you get used to it it really is quite fun. (Student 7, Entry 2)

I felt best doing my acrostic poems and my maths crossword and the writing because I found it easier and fun-ner. The maths problems were fun so yeah!...I felt I got a lot out of math because I didn't really get it at first - percentages but then I did and I felt good. (Student 3, Entry 3)

It was also clear that the students often felt stressed in regard to their assessment particularly in periods of heavy assessment at the end of term. It was interesting to note that an impacting factor on stress levels was due to the fact that students were expecting assessment to occur on a day that the teacher had set but when they went to school this was changed. One student had to wait a whole week after the originally set date to present a group assessment - causing her great anxiety and uncertainty. This student also commented on the fact that she did not particularly like group work as it was usually a disadvantage to students who wanted to do well.

I kind of appreciate doing singular or more partner things because singular you rely on yourself and you don't let other people down and it's your decision partner yeah you have that 50/50 whereas a group you can't always have your say and sometimes people let you down. (Student 5, Entry 2)

We have our religion due on Wednesday which we only found out about on Friday! I would feel a lot better if we found out when our assignments are due when we got them and if we got the criteria with them. (Student 5, Entry 4) 
It would appear from these comments that participants were not wholly aligned to peer interests and that they are keen to focus on their school work without the distraction of group dynamics.

Another found that the home situation of having to move between her mother's and father's house impacted on assessment as she often misplaced work and had problems with computer and internet access.

I don't feel too good about school this week as we have an assignment on earthquakes and it was really bad 'cause I didn't read the assignment correctly and I did a whole report on plate tectonics and that got really annoying and the internet's down now because I am at Dad's and it's not working and that's due on Monday so I am not too confident about that. Also I can't find my homework book - it's at mum's somewhere and I just don't know where it is but that is due on Tuesday so I should be alright but I also have Mathletics and that's on the internet so I can't do it so I am not so sure what I am really going to do. (Student 6, Entry 1)

This participant liked predictive structure and was keen to take responsibility for schooling requirements, but was in actuality quite out of control of their environment and so was unable to take responsibility entirely. Having a clear structure around what was expected in terms of school work and accompanying assessment was a theme throughout the students' video entries. Similarly, the structure associated with each school day and activities was equally important.

\section{Schooling Structure}

Schooling structure refers to the types of activities that are scheduled during the day as well as how students are organised within the school generally and within the classroom space more specifically. These aspects of middle years schooling are important as many of the students preferred it when they were allowed to talk in class with their friends on certain topic areas. They liked being able to have the responsibility to do independent research and have fun at the same time. It was apparent that the students liked variety in their schooling day.

I think school could have been a bit better today as we did literacy twice in a row and we were learning the same thing. What happened was that we went to one teacher and learnt something and then went to another teacher and we learnt something that was really similar and I think it was a waste of time. We did the same topic for two hours. (Student 4, Entry 3)

This week probably be doing a lot of math, English, spelling sorts, probably sport, LOTE and handball and football a lot and some tests... I am looking forward to playing with all my friends - PE rugby, LOTE. (Student 3, Entry 1)

While Student 5 indicated that working in groups was not necessarily the most appropriate mode for her for planned assessment Student 6 appreciated the time working with her friends:

I am really looking forward to doing all my assignments and I am doing one with my best friend because she is in my rotations group we can choose something out of knitting, design stuff etc and we are doing one on board games for the year 2's (Student 6, Entry 1) 
It was also evident that in the schools with a smaller student cohort participants had more opportunity to work with younger children - something that they appreciated as they were able to display leadership qualities.

In schools where there was a clear 'Middle schooling' structure and philosophy, classroom activities differed to those where Year 7 were the oldest in the school. Activities in these schools tended to remain the same as the lower grades where students participated in literacy rotations, spelling groups, and designated quiet reading time. In contrast the Middle school structure seemed to take on more of a 'high school' approach to learning in conjunction with teacher supported activities such as more focussed writing time, research and more independent (but at the same time) directed tasks.

The students spoke positively about extra-curricular options at their school. In particular when students attended camps they were excited about reporting back after the event. Attending camp allowed them to spend extended time with their friends. Additionally these activities provided leadership opportunities something that the participants highly value. It was also evident that after such experiences the confidence levels of students increased (as noted in their speech).

I have learnt a LOT in this leader's camp. When we first got there I was really nervous I wasn't really confident in myself. It was very nerve racking for me...But throughout the camp - only two days - I gained a LOT of self-confidence, "at the end I was putting my hand up for nearly everything and I was really proud of myself for that

We had many challenges to face during the camp - not physical but mental challenges. We worked very hard every day. We had teamwork and had to work on our time management. Our team did very well together. We actually had the most points at the end of the camp and so we were proud of ourselves for that.

We learn how to trust people we also learnt that to get things done sometimes you really need to push yourself and the outcome will always be great.

We had elderly people come and they told us about their childhood and what they thought made good leaders. I found it really encouraging and supportive one of them said to me you must keep on going even if you feel you are about to fall you must stay tall. It's like you are a wall you don't want to collapse you have to be strong and stable. And also to believe in yourself. (Student 4, Entry 4)

This extended transcript shows that a leadership camp for this student impacted greatly on their confidence and learning. In the diary entry the student made special note to say that a number of specific activities including: team work, being challenged physically and mentally, reading a letter from her mother, and meeting older members of the community; were life-changing moments for her. It shows that independent and reflective activities can be quite powerful for young adolescents' lifelong learning

Another interesting feature of the participants' talk was in relation to how they would like school to be structured. The boys view tended to focus on action, excitement and fun. One student listed all the things we would like at school including: Nerf guns, remote control cars, rugby union, computers, xBox and DS gaming, Freak St books and Diary of a Whimpy Kid (Student 1, Entry 2).

If I could have school my own way I would probably have like different activities such as drawing or puzzles to show like Maths or Drama which would be pretty cool or English or science maybe and we actually go outside and do really cool experiments. (Student 7, Entry 1) 
But if you were doing an unrealistic kind of school - which is pretty crazy - I would have a sort of Mythbusters school where you could like blow up stuff like cars - that would be pretty cool. (Student 7,Entry 2)

I would make it that we got two play times and some trampolines to play on during play time. I would make it that we could have a rugby, soccer and AFL fields so everyone has fun. (Student 3, Entry 1)

The girls mentioned however, that they would like to spend more time with the younger children and teaching them.

Something I would improve is the amount of time that we have with each teacher. We only get to work really with one teacher and it would good to get to know them more. I think we should also be working more with the younger guys practising our leadership skills because most of the time we don't work with them (Student 4, Entry 3).

It is apparent that these adolescents were not entirely absorbed by their peer influences and enjoyed relationships from across their communities.

\section{Friendship and Families}

Friends or friendship featured in most of the talk of the participants' entries, particularly when they spoke about what they looked forward to at school.

The only thing I really like about school is my friends. (Student 1, Entry 1)

I want to see my friends and play or just hang out with them play footy but I don't want to do any tests because I am still in weekend mode. (Student 3, Entry 2)

I am looking forward to seeing my friends as I am really close to my friends. (Student 5, Entry 1)

I am excited about tomorrow as I get to see my friends and play with them again. I am thinking of trying to make up new games for us to play. (Student 8, Entry 1)

This importance shows that early adolescents identify strongly with their peers and while their parents and family are still strong influencing factors in their lives a subtle shift to their friends sharing importance begins to occur. This is most evident when participants felt they needed support - as it was often their friends that they would turn to.

I have all my friends and we have this thing secretly so the teachers don't know we all have these arm bracelets but I think they do know they are actually hair ties but the teachers don't know they are friendship bracelets

My friends are really quite serious and supportive and all of that and if someone cries we will support them and stuff like that. My friend (--) is very supportive I have told her many many of my secrets that I haven't told before it's really good deep down for her to know exactly what has happened in my life like the splitting up of my mum and dad and many others things that happen. I am just so glad that I have a good relationship with her and I have a good relationship with my mum so it’s all really good. (Student 6, Entry 2) 


\section{Conclusion and Implications}

This study has provided some powerful insight into the perceptions and perspectives of young adolescents, particularly with regard to some key themes that have engaged researchers recently.

When given a chance to share whatever they wished to about their day over the course of a week, participants reflected on school, and for the most part positively. They enjoy learning, they like challenge and they like working with their peers in small partnerships. It would seem that they are not in a process of disengaging with school, and schooling, whether based on Middle Schooling philosophies or not, is providing a positive context for their lives. When reflecting on their schooling, participants enjoyed variety, certainly with assessment approaches, and opportunities to connect meaningfully with friends.

The most important influences in the young adolescent lives were a combination of family and friends, with a subtle shift away from family as the primary support. Interestingly though, there was not a blinkered focus on just family and peers, young adolescents enjoy connecting with the broader community across the full spectrum of ages from early childhood right through to senior citizenship. They are a part of the community, not apart from the broader community and seek opportunities to engage.

The findings from this project provided essential information about young adolescents and their perspectives on schooling. It is clear that young people are quite able to articulate their ideas and feelings and in fact appreciate the opportunity to do this. Acknowledging that young people are quite capable of making their own decisions, are prepared to carry them through, but also need advice and assistance from time to time is important for future studies on this age group.

For these participants, their adolescence is working out fine for them, and this provides a happy contrast to research that tends to paint adolescence as a period of angst, of becoming as opposed to being, and of rebellion. This in itself is an important finding with wide ranging implications for approaches to schooling in the Middle Years. Further, the use of video diaries has been an effective approach to investigating the perceptions and views of young adolescents without substantial framing by researcher expectations. 


\section{REFERENCES}

Bahr, N., \& Crosswell, L. 2011 Contesting lost ground for the middle years in Australia : using the case study of Queensland. Australian Journal of Middle Schooling, 11(2).

Bahr, N., \& Pendergast, D. 2007. The millennial adolescent. Australian Council for Education Research, Camberwell, Victoria.

Buchwald, D., Schantz-Laursen, B. \& Delmar, C. 2009. Video diary data collection in research with children: an alternative method. International journal of qualitative methods. 8(1), 13-20.

Chadbourne, R. 2003. What makes middle schools and middle schooling distinctive, if anything? QJER, 19, 3-12.

Dean, A. 2010. Gender differences in adolescents attending a drug and alcohol withdrawal service Gender differences in adolescents. Drug and alcohol review , 29 (3), 278.

Deas, D. 2009. Current State of Treatment for Alcohol and Other Drug Use Disorders in Adolescents. Alcohol research \& health, 32 (1), 76.

Gidley, J., \& Hampson, G. 2008. Integral perspectives on school educational futures. In Bussey, M., Inayatullah, S. \& Milojevic, I. (Eds.) Alternative educational futures: pedagogies for an emergent world, Rotterdam: Sense publications, 253-268.

Jackson, A., \& Davis, G. 2000 Turning Points 2000: Education adolescents in the 21st century. Teachers' College Press, New York.

Lovas, M., \& Holloway, P. 2001. Face Values. USA, Ensight Press.

Luke, A., Elkins, J., Weir, K., Land, R., Carrington, V., Dole, S., Pendergast, D., Kaptizke, C., van Kraayenoord, C., Moni, K., McIntosh, A., Mayer, D., Bahr, M., Hunter, L., Chadbourne, R., Bean, T. \& Alverman, D., Stevens, L. 2002. Beyond the middle: A report about literacy and numeracy development of target group students in the middle years of schooling. Unpublished Report for Department of Education, Science and Training.

Mealings, M., \& Douglas, J. 2010. ‘School's a big part of your life...': Adolescent perspectives of their school participation following Traumatic Brain Injury. Brain Impairment, 11(1), 116

Ministerial Council on Education, Employment, Training and Youth Affairs 2008. Melbourne declaration on educational goals for young Australians. Curriculum Corporation, Canberra.

Middle Years of Schooling Association 2008. MYSA position paper, Middle Schooling: People Practices and Places. Brisbane, QLD: MYSA.

Noyes, A. 2004. Video diary: a method for exploring learning dispositions. Cambridge Journal of Education, 34(2), 193 - 209.

Rideout, V., Roberts, D., \& Foehr, U. 2005. Generation M: Media in the lives of 8-18 Year-olds. Washington, D.C.: Kaiser Family Foundationo. Document Number).

Sessa, F.M. 1991. "Family Structure and the Development of Autonomy During Adolescence". The Journal of early adolescence , 11(1), 38.

Shanahan, T. \& Shanahan, C. 2008 Teaching Disciplinary Literacy to Adolescents: Rethinking Content-Area Literacy. Harvard Educational Review, 78(1), 40-59.

Swanson, D., Edwards, M., \& Spencer, M. 2010. Adolescence: development during a global era. London: Elsevier.

Vacca, R.T. 2002. Making a Difference in Adolescents' School Lives: Visible and Invisible Aspects of Content Area Reading. In A.E. Farstrup, \& S. Samuels (Eds.), What Research Has to Say About Reading Instruction (pp. 184-204). Newark, DE: International Reading Association.

Wormali, R. 2006. Differentiating for Tweens. Educational Leadership, 63(7), 14-19.

Zachry, C., \& Lighty, M. 1940. Emotion and conduct in adolescence. For the Commission on Secondary School Curriculum, New York: D Appleton-Century Company. 
BARTON AND BAHR: PERSPECTIVES ON SCHOOLING FROM EARLY ADOLESCENT VIDEO DIARIES

\section{ABOUT THE AUTHORS}

Dr. Georgina McFarlane Barton: Researcher, Queensland University of Technology, Australia Prof. Nan Bahr: Assistant Dean, Queensland University of Technology, Australia 

The International Journal of Technologies in Learning is one of ten thematically focused journals in the collection of journals that support The Learner knowledge community - its journals, book series, conference and online community.

The journal explores the role of technologies in learning, and processes of learning about and through technologies.

As well as papers of a traditional scholarly type, this journal invites presentations of practice-including documentation of educational technology practices and exegeses of the effects of those practices.

The International Journal of Technologies in Learning is a peer-reviewed scholarly journal.

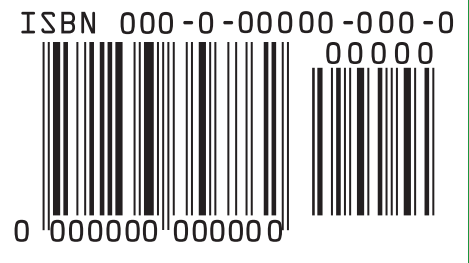

